\title{
Effect of Herbicide in Controlling Broadleaf and Sedge Weeds in Wheat (Triticum aestivum L.)
}

\author{
M. M. Kamrozzaman ${ }^{1}$, M. A. H. Khan ${ }^{2} *$, S. Ahmed $^{1}$ and A. F. M. Ruhul Quddus ${ }^{1}$ \\ ${ }^{1}$ On-Farm Research Division, Bangladesh Agricultural Research Institute, Faridpur; ${ }^{2}$ On-Farm \\ Research Division, Bangladesh Agricultural Research Institute, Mymensingh, Bangladesh \\ *Corresponding author and Email: helim1367@yahoo.com
}

Received: 18 August 2015

Accepted: 12 December 2015

\begin{abstract}
The study was conducted to assess the effectiveness of herbicide for controlling of weeds in wheat field at FSRD Site, Hatgobindapur, Faridpur during rabi 2011-12 and 2012-13. The experiment was laid out in a RCB design with five replications. There were four treatments viz. U46D fluid, ronstar 25 EC, one hand weeding and control (no weeding). Seven weed species were found in the plots and Cyperus rotundus, Cynodon dactylon, Chenopodium album were the most important weed species. Weed density and dry weight were affected significantly by different treatments. The highest weed dry weight was obtained in control while the lowest dry weight and the highest weed control efficiency were obtained from ronstar 25EC@1 ml/liter water against all types of weed species. Weed control efficiencies of ronstar 25EC against broad leaf, sedge and grass were 92, 86 and $64 \%$, respectively over control. The lowest weed control efficiency was obtained from one hand weeding treatment, which might be due to lack of proper weeding. Ronstar 25EC produced the highest grain (4.33 t/ha) and straw yields $(4.38 \mathrm{t} / \mathrm{ha})$ which were statistically identical to those of U46D fluid. The highest harvest index $(49.71 \%)$ was found in ronstar 25EC and the lowest $(41.89 \%)$ was obtained in control. The highest benefit cost ratio (2.30) was obtained from ronstar 25EC that was much higher than hand weeding (1.69). The lowest BCR (1.58) was recorded from the control. It was concluded that herbicide could be a viable alternative of manual weed control practices in wheat cultivation.
\end{abstract}

Keywords: Herbicide, sedge, broadleaf, ronstar, efficiency, harvest index, weed

\section{Introduction}

Wheat (Triticum aestivum L.) is the most important cereal crop in the world and is a major source of nourishment. In Bangladesh, it is the second major cereal crop after rice. It occupies around 3,58,180 hectares of land and makes up $6 \%$ of the cereal production from 9,95,356 tons with an average yield of $2.78 \mathrm{t} / \mathrm{ha}$ (BBS, 2012). Consumption rate of wheat is increasing day by day due to its low production cost, good market value and nutrition. Weed infestation is one of the most important factors limiting the yield of wheat. Weed infestation is a serious problem in wheat field due to moist and suitable environment favoring the growth of many noxious weed species. Weed competition during the first 10 to 50 days after sowing is the most detrimental to grain yield. Weeds belonging to family Chenopodiaceae, Cyperaceae. Gramineae, Portulaceae are the most common weeds in wheat field and cause yield loss of about 29-50\% (Singh and Gosh, 1992). Sarker et al. (1997) identified as many as 25 weed species in wheat 
field. In wheat field, major infesting weed species are broad leaf and sedge which result in a competition at early stage of growth for space, light, water and nutrients (Biswas et al., 1991).

Proper weed control measure at optimum growing period could increase the productivity of wheat. Weed control efficiency depends on weed control method, time of weeding, nature of weeds and crops. The traditional methods of weed control in Bangladesh are land tillage, hand weeding and raking in wheat fields which are time consuming, labour intensive and expensive (Chowdhury et al., 1995). Therefore, an effective, low cost and less labour intensive weed control method is essential for successful weed control on wheat field, to ensure higher yield and profitable production.

Chemical weed control has become popular to many wheat growers due to its effectiveness and low cost. Moreover, the use of herbicides has also been reported to be increasing the fertilizer use efficiency (Walia and Gill, 1985). In Bangladesh, farmers have been practicing herbicidal control methods at a very limited scale in wheat field. Most of the herbicides are postemergence and effective for controlling broadleaf and sedge weeds. A weed control method will be sustainable and popular to farmers when it is economically beneficial for crop production. In wheat cultivation a considerable portion of production costs is involved in weed control. Hand weeding and other traditional weed control methods involve high labour cost.

Ahmed et al. (2000) reported that herbicidal weed control methods are more cost effective offering an advantage to save labour and cost of production of wheat. From the above scenario, it is necessary to evaluate different weed control methods including chemical control in wheat in terms of productivity and profitability. Therefore, the study was conducted to determine an effective herbicide for the control of weeds in wheat fields and to determine the cost effectiveness of different weed control methods.

\section{Materials and Methods}

The study was conducted in Farming System Research and Development (FSRD) site of Bangladesh Agricultural Research Institute (BARI) at Hatgobindapur, Faridpur during rabi season of 2011-12 and 2012-13. The site belongs to the Low Ganges River Floodplain Agroecological Zone of Bangladesh (AEZ-12). The experimental site belongs to tropical monsoon climate with unimodal rainfall. The soils were mostly sandy to silt loam in texture and reaction was slightly acidic to alkaline having a $\mathrm{pH}$ ranging from 6.6 to 7.1 . The organic matter content of the soil was about $1.12 \%$. Nitrogen was very low but phosphorus and boron level were close to critical limit. Potassium, sulpher and Zinc content were medium in the soil. The meteorological data at the experimental site revealed that the average highest temperature $\left(28.53^{\circ} \mathrm{C}\right)$ in April and the lowest in $\left(17.85^{\circ} \mathrm{C}\right)$ and January. The relative humidity was the highest $(82.61 \%)$ in December and the lowest (63.00 \%) in April. The crop received average $(33.05 \mathrm{~mm})$ rain showers during November to April.

BARI Gom-24 was grown as the test crop in the experiment. Four different weed control treatments were imposed such as i) U46D fluid @ $1 \mathrm{ml} /$ liter water, ii) ronstar 25EC@1ml/liter water, iii) one hand weeding at 25 DAS and iv) Control (no weeding). Two post-emergence herbicides trade name, common name, active ingredient (a.i.) dose and affected weeds name are mentioned in Table 1.

The experiment was laid out in Randomized Complete Block Design (RCBD) with five replications. The unit plot size was $5 \mathrm{~m} \times 6 \mathrm{~m}$. The land was pulverized with a power tiller to ensure good tilth and levelled by a bullock drawn leveller. The fertilized were applied at 100-2633-20-5-1 kg of N-P-K-S-Zn-B/ha (FRG, 2005). All $\mathrm{P}, \mathrm{K}, \mathrm{S}, \mathrm{Zn}, \mathrm{B}$ and two-third of $\mathrm{N}$ were applied before final land preparation. The rest $\mathrm{N}$ was applied before first irrigation at crown root initiation stage (18 days after sowing). 
The crop was sown on 22 November 2011 and 25 November, 2012. Seeds were placed continuously in lines (maintaining $20 \mathrm{~cm}$ row spacing) by making narrow and shallow furrows with iron rod followed by covering with soil by hand. Whole herbicides were applied at a time in respective plots at recommended doses at 25 days after sowing. One hand weeding at 25 DAS while unweeded control plots were allowed to have weeds throughout the crop growth period.

Samples for weed density and dry weight were collected from $50 \times 50 \mathrm{~cm}$ quadrat at placed randomly selected spots in each plot at 15 DAS and 25 DAS after spraying. The collected data were transferred into $\mathrm{m}^{2}$ basis and weed samples were categorized into broadleaf, sedge and grass. Two irrigations were applied at 18 and 51 days after sowing. Intercultural operations were done properly.

At maturity, ten plants from each treatment were harvested and yield components were estimated. The economic indices like gross return, gross margin and benefit cost ratio were calculated at the prevailing local market prices. Benefit cost ratio was computed as gross return divided by total cost of cultivation.

\section{Benefit Cost Ratio $(\mathrm{BCR})=$ Gross return}

\section{Total cost of cultivation}

Grain and straw yield were taken from whole plot. The data were statistically analyzed with computer package programme MSTAT-C and the mean differences were adjudged by the least significance difference (LSD) test at 5\% level of probability (Gomez and Gomez, 1984). Pooled analysis was done as because there was no significant variation in yield and yield parameters between two years.

\section{Results and Discussion}

Considerable effects of weed control treatments on weed infestation, weed control, and yield contributing characters were observed throughout the study period. Effects of weed control treatments on individual parameters are discussed below:

\subsection{Weed flora}

The major weed species at 25 days after sowing (DAS) were observed in the research field. Seven different weed species were found belonging to six families of which five were annuals and two perennials. Local name, English name, scientific name, family, morphological types and life cycle of the weed species have been presented in Table 2 .

\subsection{Weed density}

Weed infestation was recorded at 25 DAS. At this stage purple nut-sedge (Cyperus rotundus) grass was the most dominant weed followed by Barmuda grass (Table 3). The highest absolute density $\left(62 / \mathrm{m}^{2}\right)$ and relative density $(28.57 \%)$ were recorded at purple nut sedge followed by absolute density $\left(54 / \mathrm{m}^{2}\right)$ and relative density (24.88\%) of barmuda grass. The highest dry weight was found in purple nutsedge (10.50 $\left.\mathrm{g} / \mathrm{m}^{2}\right)$ followed by pig weed $\left(7.98 \mathrm{~g} / \mathrm{m}^{2}\right)$, while the lowest dry weight was found in Indian sorrel $\left(0.15 \mathrm{~g} / \mathrm{m}^{2}\right)$. Bazzaz et al. (2011) reported similar findings.

Table 1. Trade name, common name, active ingredient (a.i.) dose of herbicides that were used in the experiment during rabi 2011-12 and 2012-13

\begin{tabular}{|c|c|c|c|c|c|}
\hline Trade name & $\begin{array}{l}\text { Common } \\
\text { name }\end{array}$ & $\begin{array}{l}\text { Active ingredient } \\
\text { (a.i.) }\end{array}$ & $\mathrm{ml} / \mathrm{ha}$ & Weed affected & Characteristics \\
\hline U46D fluid & $2,4 \mathrm{D}$ & $480 \mathrm{~g} / 1$ & 500 & Post-emergence & Sedge \\
\hline Ronstar $25 \mathrm{EC}$ & Oxadiazon & $250 \mathrm{~g} / 1$ & 500 & Post-emergence & $\begin{array}{c}\text { Sedge and broad } \\
\text { leaf }\end{array}$ \\
\hline
\end{tabular}


Table 2. Weed species found in the experimental plots of wheat during rabi 2011-12 and 2012-13

\begin{tabular}{cclcccc}
\hline $\begin{array}{c}\text { Sl. } \\
\text { No }\end{array}$ & Local Name & English Name & Scientific Name & Family & $\begin{array}{c}\text { Morpholo- } \\
\text { gical type }\end{array}$ & Life cycle \\
\hline 01 & Bathua shak & Goose foot & Chenopodium album & Chenopodiaceae & Broadleaf & Annual \\
02 & Nunia & Pig weed & Portulaca oleracea & Portulaceae & Broadleaf & Annual \\
03 & Amrul shak & Indian sorrel & Oxalis europea & Oxalidaceae & Broadleaf & Annual \\
04 & Bon palong & Golden dock & Rumex maritius & Polygonaceae & Broadleaf & Annual \\
05 & Mutha & Purple nutsedge & Cyperus rotundus & Cyperaceae & Sedge & Annual \\
06 & Durba ghas & Barmuda grass & Cynodon dactylon & Gramineae & Grass & Perennial \\
07 & Bisha grass & Scab grass & Digitaria sanguinalis & Gramineae & Grass & Perennial \\
\hline
\end{tabular}

Table 3. Weed density and dry weight of different species in wheat field before spraying (25 DAS) during rabi 2011-12 and 2012-13 (pooled)

\begin{tabular}{cllccc}
\hline Sl. No. & English Name & Scientific Name & $\begin{array}{c}\text { Absolute } \\
\text { density } \\
\left(\mathrm{no}^{2} / \mathrm{m}^{2}\right)\end{array}$ & $\begin{array}{c}\text { Relative } \\
\text { density } \\
(\%)\end{array}$ & $\begin{array}{c}\text { Dry } \\
\text { weight } \\
\left(\mathrm{g} / \mathrm{m}^{2}\right)\end{array}$ \\
\hline 01 & Goose foot & Chenopodium album & 25 & 11.52 & 4.20 \\
02 & Pig weed & Portulaca oleracea & 12 & 5.52 & 7.98 \\
03 & Indian sorrel & Oxalis europea & 16 & 7.37 & 0.15 \\
04 & Golden duck & Rumex maritius & 18 & 8.29 & 0.19 \\
05 & Purple nutsedge & Cyperus rotundus & 62 & 28.57 & 10.50 \\
06 & Barmuda grass & Cynodon dactylon & 54 & 24.88 & 6.45 \\
07 & Scab grass & Digitaria sanguinalis & 8 & 3.68 & 1.72 \\
08 & Others & - & 22 & 10.14 & 2.6 \\
\hline Total & & & 217 & 100 & 33.79 \\
\hline CV $(\%)$ & - & - & 5.80 & 6.46 & 5.06 \\
LSD $(0.05)$ & & & 1.33 & 0.54 & 0.38 \\
\hline
\end{tabular}

Table 4. Broad leaf, sedge and grass weeds as influenced by different weed control treatments in wheat field at 15 days after spraying during rabi 2011-12 and 2012-13 (pooled)

\begin{tabular}{|c|c|c|c|c|c|c|c|}
\hline \multirow[t]{2}{*}{ Treatments } & \multicolumn{4}{|c|}{$\begin{array}{c}\text { Broad leaf } \\
(\text { No. })\end{array}$} & \multirow{2}{*}{$\begin{array}{c}\text { Sedge (No.) } \\
\text { Cyperus } \\
\text { rotundus }\end{array}$} & \multicolumn{2}{|c|}{$\begin{array}{l}\text { Grass } \\
\text { (No.) }\end{array}$} \\
\hline & $\begin{array}{c}\text { Chenopodium } \\
\text { album }\end{array}$ & $\begin{array}{l}\text { Rumex } \\
\text { maritius }\end{array}$ & $\begin{array}{c}\text { Portulaca } \\
\text { oleracea }\end{array}$ & $\begin{array}{c}\text { Oxalis } \\
\text { europea }\end{array}$ & & $\begin{array}{l}\text { Cynodon } \\
\text { dactylon }\end{array}$ & $\begin{array}{c}\text { Digitaria } \\
\text { sanguinalis }\end{array}$ \\
\hline U46D fluid & 7 & 10 & 2 & 3 & 14 & 18 & 16 \\
\hline Ronstar25EC & 3 & 4 & 1 & 2 & 11 & 10 & 8 \\
\hline One hand weeding & 21 & 19 & 7 & 10 & 27 & 25 & 27 \\
\hline Control & 35 & 26 & 21 & 38 & 81 & 72 & 32 \\
\hline$\overline{\mathrm{CV}(\%)}$ & 6.14 & 5.92 & 6.80 & 5.49 & 5.60 & 6.98 & 5.49 \\
\hline LSD (0.05) & 0.26 & 1.23 & 0.30 & 0.27 & 0.27 & 0.85 & 0.43 \\
\hline
\end{tabular}




\subsection{Effect on weed flora}

The number of weed population counted at 15 days after spraying. The weed density was reduced and varied remarkably due to application of different weed control measures except control (Table 4). All herbicidal treatments were found effective in controlling the broad leaf, sedge and grass weeds. The herbicide ronstar 25EC was found most effective to control broad leaf, sedge and grass weeds. The herbicide U46D was less effective to control grass weed than Ronstar 25EC. The result is in agreement with that of Bazzaz et al. (2011), who reported that U46D fluid was less effective in controlling the grass weeds. Moreover, only one hand weeding treatment was not effective in controlling all types of weed in wheat field. Bhagat and Jain (1985) reported that both herbicide and hand weeding decreased the density and dry weight of weeds significantly. Herbicide effectively reduced the number and dry weight of purple nut sedge also reported by Rahnavarid et al. (2010).

\subsection{Weed control efficiency}

Weed control efficiency varied depending on the effectiveness of different weed control measures to control weed (Table 5). Ronstar 25EC herbicide showed the highest weed control efficiency against all type of weed species followed by U46D fluid. Ronstar 25EC was found comparable to that of hand weeding in controlling the most weed species expect cynodon dacrylon. The result is in agreement with that reported by Biswas et al. (1991). Mahmood and Sandhu (1988) concluded that herbicides control $80-90 \%$ weed in the high weed infested fields.

Table 5. Weed dry weight and weed control efficiency as affected by different weed control treatments during rabi 2011-12 and 2012-13 (pooled)

\begin{tabular}{lcccccc}
\hline \multirow{2}{*}{ Treatments } & \multicolumn{3}{c}{$\begin{array}{c}\text { Dry weight of weeds at 15 days after } \\
\text { spraying }\left(\mathrm{g} / \mathrm{m}^{2}\right)\end{array}$} & \multicolumn{3}{c}{$\begin{array}{c}\text { Weed control efficiency } \\
(\%)\end{array}$} \\
\cline { 2 - 7 } & Broad leaf & Sedge & Grass & Broad leaf & Sedge & Grass \\
\hline U46D & 1.27 & 2.37 & 3.6 & 81 & 83 & 44 \\
Ronstar25EC & 0.53 & 1.86 & 2.3 & 92 & 86 & 64 \\
One hand weeding & 3.70 & 4.57 & 5.7 & 44 & 67 & 11 \\
No weeding & 6.65 & 13.72 & 6.4 & - & - & - \\
\hline CV (\%) & 6.89 & 5.73 & 6.05 & - & - & - \\
LSD (0.05) & 0.07 & 0.13 & 0.12 & - & - & - \\
\hline
\end{tabular}

Table 6. Yield and yield attributes of wheat as affected by different treatments during rabi 2011-12 and 2012-13 (pooled)

\begin{tabular}{lccccccc}
\hline \multicolumn{1}{c}{ Treatment } & $\begin{array}{c}\text { Plant } \\
\text { height } \\
(\mathrm{cm})\end{array}$ & $\begin{array}{c}\text { Spikes/ } \\
\mathrm{m}^{2} \\
(\text { No. })\end{array}$ & $\begin{array}{c}\text { Grains/ } \\
\text { spike } \\
(\text { No. })\end{array}$ & $\begin{array}{c}1000 \\
\text { grain } \\
\text { wt. }(\mathrm{g})\end{array}$ & $\begin{array}{c}\text { Grain } \\
\text { yield } \\
(\mathrm{t} / \mathrm{ha})\end{array}$ & $\begin{array}{c}\text { Straw } \\
\text { yield } \\
(\mathrm{t} / \mathrm{ha})\end{array}$ & $\begin{array}{c}\text { Harvest } \\
\text { index } \\
(\%)\end{array}$ \\
\hline U46D fluid & 93.32 & 229 & 38.26 & 54.08 & 4.20 & 4.36 & 49.07 \\
Ronstar 25EC & 94.56 & 225 & 38.88 & 53.88 & 4.33 & 4.38 & 49.71 \\
One hand weeding & 88.56 & 204 & 34.62 & 53.16 & 3.64 & 3.83 & 47.64 \\
Control & 77.06 & 185 & 32.92 & 53.12 & 2.22 & 3.08 & 41.89 \\
\hline CV $(\%)$ & 6.26 & 7.83 & 6.34 & 6.01 & 6.00 & 9.08 & - \\
LSD $(0.05)$ & 2.83 & 22.75 & 1.66 & NS & 0.32 & 0.61 & - \\
\hline
\end{tabular}


Table 7. Cost and return analysis of wheat in controlling weeds by different weed control methods at FSRD site, Hatgobindapur Faridpur during rabi 2011-12 and 2012-13 (average of two years)

\begin{tabular}{lcccc}
\hline \multicolumn{1}{c}{ Treatments } & Gross return (Tk./ha) & Total cost (Tk./ha) & Gross margin (Tk./ha) & BCR \\
\hline U46D fluid & 88360 & 39233 & 49127 & 2.25 \\
Ronstar25EC & 90980 & 39547 & 51433 & 2.30 \\
One hand weeding & 76630 & 45216 & 31414 & 1.69 \\
Control & 47480 & 30052 & 17428 & 1.58 \\
\hline
\end{tabular}

Note: price of grain=Tk.20.00/kg and straw $=$ Tk. $1.00 / \mathrm{kg}$

\subsection{Yield and yield contributing characters as affected by different weed control methods}

Yield and yield contributing characters as well as harvest index of wheat were significantly influenced by different weed control methods (Table 6). Plant height ranged from 77.06-94.56 $\mathrm{cm}$. The maximum plant height $(94.56 \mathrm{~cm})$ was attained in ronstar $25 \mathrm{EC}$ treatment but at par to U46D fluid treatment $(93.32 \mathrm{~cm})$. The shortest plants $(77.06 \mathrm{~cm})$ were observed in control treatment. The shortest plants were observed where weed control efficiency was low and the tallest plants were found when weed control efficiency was more which was supported by Subhan (2007). Weed control methods caused considerable effect on number of spike per $\mathrm{m}^{2}$. Spike density varied from 185 to 229 per $\mathrm{m}^{2}$. The highest number of spike per $\mathrm{m}^{2}$ was observed in U46D fluid treatment which was statistically similar to ronstar 25EC treatment. Control treatment produced the lowest (185) number of spike per $\mathrm{m}^{2}$ but at par to one hand weeding treatment. This results were in agreement with those reported by Bazzaz et al. (2011) who found the highest number of spike per $\mathrm{m}^{2}$ was recorded in wheat with U46D fluid @ $1500 \mathrm{ml}$ per ha and the lowest in control plots.

Filled grains per spike varied significantly among the treatments. The maximum number of grains/spike (38.88) was observed in ronstar 25EC treatment followed by U46D fluid. Both the herbicides showed least crop weed competition that ensured sufficient nutrients for plant and produced higher number of filled grains. The lowest grains/spike (32.92) was produced by control treatment. It might be due to severe infestation of weeds and lower amount of assimilate production by this treatment resulting in lower availability of resources and yield. Weight of 1000 grains was not significantly influenced by different treatments.

Different weed control treatments significantly influenced grain yields. Grain yield ranged from 2.22 to $4.33 \mathrm{t} / \mathrm{ha}$. The highest yield $(4.33 \mathrm{t} / \mathrm{ha})$ was obtained from ronstar 25EC treatment followed by U46D fluid. The lowest grain yield $(2.22 \mathrm{t} / \mathrm{ha})$ was obtained from the control treatment which was due to crop weeds competition that resulted in low dry matter and ultimately lower yield. Among the treatments, ronstar 25EC, U46D fluid and one hand weeding treatment produced 32, 30 and $13 \%$ higher yield, respectively over control. Straw yield was also influenced by different weed control treatments. The lowest straw yield was produced by control treatment $(3.08 \mathrm{t} / \mathrm{ha})$ that was similar to one hand weeding treatment. The maximum straw yield was found in ronstar 25EC treatment $(4.38 \mathrm{t} / \mathrm{ha})$ followed by U46D fluid treatment which was statistically at par.

\subsection{Harvest index}

The highest harvest index (49.71\%) was observed in ronstar 25EC treatment which was very close to U46D fluid treatment (Table 6). The lowest harvest index $(41.89 \%)$ was found in control treatment. The results revealed that wheat field which kept weed free care ensure higher grain yield as well as higher harvest index. 


\subsection{Cost and return analysis}

The highest gross return (Tk. 90,980/ha) and gross margin (Tk. 51,433/ha) were recorded from ronstar 25EC treatment which was closely followed by U46D fluid treatment. The lowest gross return (Tk. 47480/ha) and gross margin (Tk. 17428/ha) were recorded from control treatment (Table7). It is seen that the application of herbicides offered better benefit cost ratio than that of one hand weeding. Ronstar 25EC and U46D fluid treatment showed similar benefit cost ratio (2.30) and which was higher than one hand weeding. The lowest benefit cost ratio was observed in control treatment (1.58) that was closely followed by one hand weeding. So, it was revealed that herbicidal weed control is profitable as well as an alternative when labour is a limiting factor in wheat production. Singh and Gosh (1992) reported that weed control in wheat through herbicides are more economic than hand weeding.

\section{Conclusions}

Among the weeds, Cyperus rotundus, Cynodon dactylon and Chenopodium album were the major infesting weed species in the wheat field. Ronstar 25EC showed higher weed control efficiency than U46D fluid. Among the treatments used in the study, ronstar 25EC produced the highest grain yield (4.33 t/ha), harvest index $(49.71 \%)$ as well as gross return. The highest benefit cost ratio (2.30) was obtained from the ronstar 25EC against one hand weeding (1.69). Thus, it might be reasonably concluded that herbicide could be a viable alternative of manual weed control practices in wheat cultivation.

\section{References}

Ahmed, G. J. U., Mamum, A. A., Hossain, S. M. A., Mridha and Hossain, S.T. 2000. Agroeconomic study of weeds control in direct seeded Aus rice in the farmers' field. Annals of Bangladesh Agriculture, 8 (2): 111-118.
Bazzaz, M. M., Hossain. A. and Sarkar, M. A. 2011. Effect of different doses of U46D on weed control especially Cyperus rotundus in wheat. Bangladesh Journal of weed Science, 2 (1\&2): 73-77.

BBS (Bangladesh Bureau of Statistics), 2012. Year Book of Agricultural Statistics of Bangladesh. Planning Division, Ministry of Planning, Government of People's Republic of Bangladesh. Dhaka. Published in August, 2013.

Bhagat, K. L. and Jain, H. C. 1985. Influence of herbicides on weeds and on growth, yield and quality of wheat. Weed Abstract, 35(1): 1843-86.

Biswas J. C. Satter, S. A. and Siddique, S. B. 1991. Evaluation of herbicides in direct seeded rice. Bangladesh Journal of Rice, 2(1-2): 40-45.

Chowdhury M. A. H., Talukder, A. K. and Hossain, M. Z. 1995. Effect of Ronstar 25EC on weed management, yield and nutrient uptake by rice. Bangladesh Journal of Agricultural Science, 22 (1): 93-98.

FRG (Fertilizer Recommendation Guide), 2005. Bangladesh Agricultural Research Council. Farmgate, New Airport Road, Dhaka-1215, Bangladesh.

Gomez, K. A. and Gomez, A. A. 1984. Statistical procedures of Agricultural Research, $2^{\text {nd }}$ edn., John Wiley and Sons, Inc. 605 Third Avenue, New York. 2030pp.

Mahmood, T. Z. and Sandhu, G. R. 1988. Studies on chemical and mechanical weed control in Barany wheat. Pakistan Journal of Weed Science Research, 1(2): 123-126.

Rahnavarid, A., Ashrafi, Z. Y., Rahbari, A. and Sadeghi, S. 2010. Effect of different herbicide on control of purple nutsedge (Cyperus rotundus L). Pakistan Journal of Weed Science Research, 16(1): 57-66. 
Sarker, M. A. Z., Mian, M. G., Hamid, A., Haider, J. and Hashem, A. 1997. Effect of nitrogen level and duration of weed competition on biomass and yield attribute of wheat. Annals of Bangladesh Agriculture, 7 (1): 1-17.

Singh, R. D. and Ghosh, A. K. 1992. Evaluation of herbicides for control of wild oat (Avena ludoviciana Durr.) in wheat. Indian Journal of Agronomy, 37(2): 327331.
Subhan, F. 2007. Response of maize crop to various herbicides. Pakistan Journal of Weed Science Research, 13(1-2): 9-15.

Walia, U. S. and Gill, H. S. 1985. Interactions between herbicides and nitrogen in the control of phalaris minor in wheat. Tropical Pest Management, 31(3): 226231. 